\title{
The high 'price' of dematerialization: A dynamic panel data analysis of material use and economic recession
}

Qinglong Shao ${ }^{1}$, Anke Schaffartzik ${ }^{2}$, Andreas Mayer ${ }^{2}$, Fridolin Krausmann².

${ }^{1}$ Corresponding author: Institute of Environmental Sciences and Technology, Autonomous University Barcelona

${ }^{2}$ Institute of Social Ecology (SEC), Alpen-Adria University Klagenfurt-Graz-Wien, Schottenfeldgasse 29, 1070 Vienna, Austria

Accepted final version of:

Shao, Q., Schaffartzik, A., Mayer, M., Krausmann, F. 2017. The high 'price' of dematerialization: A dynamic panel data analysis of material use and economic recession, Journal of Cleaner Production, 167 (2017) 120-132.

https://doi.org/10.1016/j.jclepro.2017.08.158. 


\begin{abstract}
:
Dematerialization at the national level occurs almost exclusively during periods of economic recession or low growth. While recession is not a sustainable strategy to curb environmental impact, such periods may offer important insights on the possibilities of reducing material use. Economic recession research has focused on the interactions between macroeconomic and financial variables with little systematic research dedicated to uncovering how resource use develops during periods of recession. Using a dynamic panel model, we investigate whether and to what extent material use in a sample of 150 economies between 1970 and 2010 was affected by recession and low growth. Recession occurred most frequently and in more than two thirds of all countries during the 1980s and the 1990s. In the 2000s, more than half of the recessions occurred during the financial crisis of 2008. Periods of recession were significantly and negatively correlated with material use - they tended to coincide with dematerialization. Material use decreased in recession years, but the significant correlations with growth in material use became weaker as growth rates increased. Construction minerals and metals, used to build stocks of manufactured capital, reacted more strongly to economic fluctuations than the throughput-dominated flows of biomass and fossil fuels. We conclude that the systematic link between recession and dematerialization can become policy-relevant if the mechanisms causing reductions in material use during these periods are identified.
\end{abstract}

Keywords: economic recession; low growth; panel data analysis; material use; dematerialization. 


\section{Introduction: Economic development and material flows}

Global material use has increased from approximately 7 billion tons (Gigatons Gt) in the year 1900 (Krausmann et al., 2009) to approximately 70 Gt in 2010 (Schaffartzik et al., 2014). The extraction and use of these large and growing quantities of resources are related to a broad range of sustainability problems and a decoupling of material use and economic development is considered imperative for sustainable development (UNEP, 2011). It has been shown that, however, significant improvements in material efficiency in the past have not lead to an overall reduction of material use (UNEP, 2016a) Different pieces of evidence point towards economic recession as an important factor in absolute, but ultimately short-term, reductions of material use (e.g., Steinberger et al., 2013). Recession is neither a socially nor an economically sustainable strategy in curbing human societies' impact on the environment but insights on the possibilities of material use reduction might be gained by studying periods characterized by negative economic growth. We have applied a dynamic panel data approach to 150 economies between 1970 and 2010 in order to generate systematic results on the relationship between economic recession and development of material use.

Recession may be defined by decline in economic output per capita (Barro and Ursúa, 2008; Kehoe and Prescott, 2002), by a combination of declining per capita output and negative economic growth (Breuer and McDermott, 2013), or by decline in economic output over a set period of time (Claessens et al., 2009). For the purposes of our study, which relies on annual material flow data, we identified as recession years those years in which economic output declined (Reddy and Minoiu, 2009; Burke et al., 2015). Most of the research on recession, by any definition, has, to date, focused on linkages among economic variables and on very severe recessions, i.e., depressions. Claessens et al. (2009) studied linkages between key macro-economic and financial variables, such as inflation, debt, and unemployment in 21 member countries of the Organization for Economic Co-operation and Development (OECD). Breuer and McDermott (2013) comprehensively and globally analyzed economic depression in the 
world, across long periods of time and for countries and regions of different development levels, and were able to identify economic, financial, political, and cultural aspects typically associated with depression and also found that domestic and international shocks played an important role in determining the onset or the end of a period of depression. Fisher and Hornstein (2002) focused on Germany during the Great Depression of 1928-37 and found that real wages were countercyclical, i.e., they were not correlated with the changes in economic output, while productivity and fiscal policy were procyclical. Other country-level case studies on economic depression have included Argentina (Kydland and Zarazaga, 2002), Chile and Mexico (Bergoeing et al., 2002), and Japan (Hayashi and Prescott, 2002). The latter study concluded that the underlying reasons for recession during Japan's "Lost Decade" may have been rooted in the low growth of productivity rather than in the development of the financial system and the capital markets. For the 20-year depression in the United Kingdom between the two World Wars, Cole and Ohanian (2002) identified high unemployment benefits and negative sectoral shocks as leading explanatory variables.

With regard to the linkages between economic development and the environment which a recession may bring to light, the relationship with material use has not yet been systematically analyzed. Bringezu et al. (2004) noted that individual countries' direct material input $(\mathrm{DMI}=$ domestic extraction plus imports $)$ did change during periods of economic recession, but the specific relation could not be generalized across countries. For Finland, the authors noted that very high levels of material flows had preceded the economic recession. At the aggregate global level, Krausmann et al. (2009) demonstrated that periods of economic recession (during and after the two World Wars and during the world economic crisis 1930-32) coincided with periods of declining domestic material consumption $(\mathrm{DMC}=$ domestic extraction plus imports minus exports). The years following the oil price peaks (1973, 1979 and 1988) with their reduced levels of GDP growth were periods of stagnation in global material use. In the development of mineral and fossil fuel use during years of recession, Steinberger et al. (2013) found evidence for short-term coupling between material resource flows and 
economic development. While many authors mention evidence for a link between economic recession and material use patterns in passing (Behrens et al., 2007; Rogich, 1996; Russi et al., 2008; Vehmas et al., 2007; Ewijk and Stegemann, 2016; Schandl et al., 2016; Mirabella et al., 2013 ;Giljum et al., 2014), a systematic analysis of this link is not yet available. The aim of this study is to fill this gap by providing a quantitative analysis of material use patterns in periods of economic recession at the national level. Based on the scattered evidence for a close relation between dematerialization and low economic growth from previous studies (e.g., Steinberger et al., 2013; Krausmann et al., 2009; Giljum et al., 2014) we here assume that periods of exceptionally low GDP growth and in particular of recession have a significant negative impact on DMC and that this effect differs across the main material groups. We further assume that this effect is stronger than that of other important socio-economic variables. We use a dynamic panel data model covering 150 economies to detect whether recession or low growth are determining factors for material flows, among other potential impact factors. We consider total material flows as well as material flows by material type (biomass, fossil fuels, construction and industrial minerals, and metal ores) in order to reflect potential differences in the links of material types to economic development. Such analysis contributes to a systematic understanding of the close interrelations between economic growth and material use at the national level, and subsequently provides a backdrop for in-depth case studies on wider consequences of economic recession on societal resource use (Chiu et al., 2017; Dong et al., 2017). Our findings are also directly policy-relevant: It is becoming increasingly clear that in order to curb the environmental impact of socio-economic activity, resource use levels must be reduced in absolute terms (Akenji et al., 2016; Schandl et al., 2017). If, however, economic recession has previously constituted a prerequisite to reductions in material use (which we investigate in this article), then the challenge of finding viable and effective ways to deal with the environmental crisis is much greater than previously anticipated.

\section{Methods and data}


In assessing the role which economic recession plays for material use levels, we require an analytic approach which allows us to study the relationship between these two (and other background) variables. We must assume that the material use levels are prone to feedback over time. This requires a dynamic model that can capture time lags in the material variable, such as, allowing past material use levels to influence current material use levels. "Static" panel techniques, as regularly used for empirical analysis, do not incorporate any temporal dependency (lags) of the dependent variable, neglecting the fact that environmental indicators (such as $\mathrm{CO}_{2}$ emission, energy use, or ecological footprint) are likely to correlate strongly over time. Thus, in order to control for the dynamics of the process and test whether significant correlations still explicitly exist under this new framework, we employed a dynamic panel technique that contains lagged dependent variable among the regressors. In this line, we construct a dynamic panel data model of the form below:

$$
D M C_{i, t}=a D M C_{i, t-1}+\text { bRecession }_{i, t}+\text { cLowGrowth }_{i, t}+d X_{i, t}+\mu_{i}+\varepsilon_{i, t}
$$

The dependent variable $D M C_{i, t}$ denotes the domestic material consumption in country $i$ and year $t$. Our data cover 41 years (1970-2010), so that $t=1,2, \ldots, 41$, and 150 economies, so that $i=1,2, \ldots, 150$. The number of countries for which data are available $(\mathrm{N}=150)$ is large compared to the time periods for which data are available $(\mathrm{T}=41)$, so that our dataset has the particular structure "large $\mathrm{N}$ and small $\mathrm{T}$ ". We elaborate the model for total DMC here and have also analyzed DMC by material types (biomass, fossil fuels, industrial and construction minerals, metal ores; also see Table 1). The independent variable $D M C_{i, t-1}$ is the time-lagged dependent variable, i.e., the material consumption in country $i$ in the year preceding $t$. We have chosen a first order of time lag. Recession ${ }_{i, t}$ denotes whether the country $i$ was in recession (i.e., experienced negative GDP growth) in year $t$ (and then takes on the value 1) or not (in which case this variable has the value 0 ). We thereby reduce economic growth to a 
binary variable which allows us to generate an unambiguous answer to the question of whether or not dematerialization only occurs during periods of recession. In order to capture quantitative differences in economic growth, we introduced a variable which allows us to capture different levels of growth: Low Growth ${ }_{i, t}$ takes on the value 1 if country $i$ experiences low growth (we distinguish three low growth levels between $0 \%$ and 3\% GDP growth per year, see Table 1) in year $t$ and takes on the value 0 if this is not the case. A country can thereby either be in recession or low growth or neither in yeart.

It is worth noting that the actual GDP growth rate is a good indicator to examine the elasticities of GDP on material use, however, this would generate very similar effects among the different growth ranges, not providing additional insight for our main research question. For example, Burke et al. $(2015$, p.111) employed the precise growth figure in order to check for the asymmetric effects of positive and negative GDP growth but use a binary variable to represent 'boom' or 'recession' phases. With our approach we follow previous studies which used the binary dummy to represent recession such as Breuer and McDermott (2013, p.234), Claessens et al. (2009, p.686).

$X_{i, t}$ is a vector of possible socio-economic drivers of material use: GDP per capita, population, the urban population share, the share of value added in the services sectors in GDP, the ratio of monetary exports and imports to GDP, respectively, a time-lagged technology indicator, and a dummy variable of signature of the Kyoto Protocol which takes on the value of 1 from 1998 onwards (see section 2.2). The variables contained in $X_{i, t}$ vary over time (differ according to $t$ ) and across countries (differ according to $i$ ). All indicators except for the dummy variables (i.e., recession, the three growth variables, and the signature of the Kyoto Protocol) are logarithmized rendering a log-log regression model ${ }^{1}$. The regression coefficient therefore corresponds to the elasticity between the dependent and the explanatory variable. i.e., the percentage of change in the dependent variable caused by a one percent change in the explanatory variable,

1 Note: in the regression, zero values were not be logarithmized. 
holding other variables unchanged. $\mu_{i}$ represents the unobserved effects which are specific to country $i$ but are time-invariant. Because these effects are stochastic $\left(\mu_{i} \sim i . i . d\left(0, \sigma_{\mu_{i}}\right)\right)$, they are necessarily correlated with the time-lagged dependent variable. $\varepsilon_{i, t}$ is a stochastic disturbance term $\left(\varepsilon_{i, t} \sim\right.$ i.i.d $\left.\left(0, \sigma_{\varepsilon}\right)\right)$. The expected value (or weighted average) $E\left(\mu_{i}, \varepsilon_{i, t}\right)=0$.

Since the time-lagged explanatory variable is positively correlated with the error term $\left(\mu_{i}+\varepsilon_{i, t}\right)$, we cannot use ordinary least squares to estimate the regression coefficient of the time-lagged variable. Instead, we employ the Arellano-Bond (AB) generalized method of moments (GMM) estimator (Arellano and Bond, 1991; Roodman, 2010). This estimator was developed and extended to the system GMM context (Blundell and Bond, 1998) for dynamic models of panel data characterized by "large $\mathrm{N}$ and small $\mathrm{T}$ ", explanatory variables that are not strictly exogenous, and heteroscedasticity within the errors (by but not across countries, in our case) as is the case in our dataset and dynamic model. The system GMM estimators afford the advantage of relying on instruments available within the panel. In a system of two simultaneous equations, the first-differenced equation (with lagged levels of explanatory variables as instruments) is combined with the levels equation (with lagged first differences of the explanatory variables as instruments) (Nguyen et al., 2014).

Three criteria are employed in our analysis to test the results. First, we test for autocorrelation in the errors by using the Arellano-Bond AR(1) and AR(2). Specifically, $\mathrm{AR}(1)$ tests for first order serial correlated residues and $\mathrm{AR}(2)$ tests for serial uncorrelated residues of second order. We reject the result if for $\mathrm{AR}(1) \mathrm{P}<0.05$ but accept the result if for $\mathrm{AR}(2) \mathrm{P}>0.05$. In addition, the Sargan test was used to check instrument validity which was considered reasonable if the Sargan P-values did not reject the null hypothesis (H0: over-identifying restrictions are valid). A rule-of-thumb is that the number of instruments should be less than the number of counties (Schumacher, 2014). 


\subsection{Dependent variables: material flow data}

The dependent material consumption variables in our dynamic model were derived from material flow data. This data is obtained by material flow accounting (MFA) which is one of the key methods in environmental accounting (Fischer-Kowalski et al., 2011). The annual material flow data for a global country sample used in our analysis was obtained from the United Nations Environment Programme (UNEP) material flow dataset (UNEP, 2016; Schandl et al., 2017) available for download at https://uneplive.unep.org/material\#.WjxRc_KnTVJ. This database is the most comprehensive and up-to-date global MFA database currently available and contains detailed material flow data at the national level in kilotons per year $(\mathrm{kt} / \mathrm{a})$, covering the period 1970 to 2010. Based on this data, we calculated domestic material consumption $(\mathrm{DMC}=$ domestic extraction plus imports minus exports) by main material group (biomass, fossil fuels, non-metallic minerals, and metal ores) and in total. Biomass comprises products from agriculture, forestry, fishing, and hunting. Fossil fuels encompass coal and peat, oil, and natural gas as well as any derived products. Nonmetallic minerals comprise all minerals for industrial use and construction. Metal ores include all metallic ores, metals and derived products. The DMC indicator does not include unused or upstream flows related to imports or exports (Fischer-Kowalski et al., 2011).

The period between 1970 and 2010 comprises the dissolution of the USSR, Czechoslovakia, and Yugoslavia. We included these economies in our data panel until the year of their dissolution and then accounted for the independent countries that emerged from them. The numbers of economies for which data are available differ from one year to the next (also see Table 1).

\subsection{Independent variables: socio-economic data}

The primary source of data for the independent or explanatory variables was the World Development Indicators Database (World Bank, 2016). While some of these variables are commonly used in studies relating socio-economic development to 
environmental factors, others (such as the recession variable and the technology variable) constitute aspects which have not been taken into account by previous studies.

We seek to understand the relationship between material use and economic recession. The Recession indicator is therefore central to our analysis. This variable is based on GDP growth in annual \% as reported by the World Bank (2016) in its World Development Indicators, i.e., based on annual average in constant prices. The Recession indicator takes the value of 1 if GDP decreases (i.e., during years with negative economic growth) and of 0 in all other years, following the definition of recession used by Reddy and Minoiu (2009) and Burke et al. (2015). Literature on economic growth typically considers growth rates of around 3\% as "normal" (Malmaeus and Alfredsson, 2017; Alfredsson and Malmaeus, 2017). Hence, we have chosen 3\% as an upper boundary for our analysis. The low economic growth indicator can take on one of three levels: 1) GDP growth rates ranging between 0-1\% ("very low growth"), 2) GDP growth between 1-2\% ("low growth"), and 3) GDP growth between 2-3\% ("normal growth"). For each of these levels, this indicator takes on the value of 1 if the low growth criterion is met and of 0 if this is not the case.

Our aim is to design a dynamic model which allows us to investigate the effect of socio-economic variables on material use across countries and over time. We therefore added several potentially important socio-economic control variables to the model:

1) Real GDP per capita (GDP p.c) in US\$ in constant 2005 prices in order to allow for an impact of income on material use,

2) Total population (Population), which is essential to account for size differences across countries,

3) Urban population ratio (Urban $\% P$ ) as a proxy for the population living under the industrial socio-metabolic mode, i.e., depending on a fossil fuel based energy system (Fischer-Kowalski and Schaffartzik, 2015),

4) Value added by the services sector as percentage of GDP (Service \% GDP) as a proxy for economic structure, 
5) Exports and imports of goods and services in percentage of GDP (Export \% $G D P$ and Import \% GDP) to capture the role of trade for the country,

6) Number of patents filed under the Patent Cooperation Treaty (Technology (t-1)) as an indicator for technology. This variable is lagged by one year (t-1) to account for the time lag in patent diffusion (Bayer et al., 2013; Cheon and Urpelainen, 2012). Data were sourced from the OECD Patent Statistics Portal (Version, 2011) ${ }^{2}$, and

7) Signature of the Kyoto Protocol $(K P)$ as a dummy variable which takes on the value 1 after the signing of the Kyoto Protocol in 1998 and of 0 before that. We chose this variable in order to test the results of previous studies which showed an effect of the Kyoto Protocol on $\mathrm{CO}_{2}$ emissions (Aichele and Felbermayr, 2014).

All the selected variables and their summary statistics are provided in Table 1, which contains the definition, numbers of observations, descriptive statistics and sources. It shows that for both the dependent and independent variables, there is considerable variation across observations

\footnotetext{
2 Patent data can be non-integer because when a patent was invented by several inventors from different countries, the respective contributions of each country is taken into account. This is done in order to eliminate multiple counting of such patents (OECD Patent Statistics Portal (Version, 2011)).
} 
Table 1. Summary Statistics

\begin{tabular}{|c|c|c|c|c|c|c|c|}
\hline \multirow[t]{2}{*}{ Variables } & \multirow[t]{2}{*}{ Definition and units } & \multirow[t]{2}{*}{ Observations } & \multicolumn{4}{|c|}{ Descriptive Statistics } & \multirow[t]{2}{*}{ Source } \\
\hline & & & Mean & Std. Dev & Min & Max & \\
\hline \multicolumn{8}{|l|}{ Material variables } \\
\hline$D M C$ & Domestic material consumption, kilotons [kt] & 6150 & $253,004.3$ & $946,360.3$ & 0 & $2.36 \mathrm{e}+07$ & \multirow{5}{*}{ UNEP (2016) } \\
\hline DMC-Biomass & Biomass [kt] & 6150 & $81,491.35$ & 240,195 & 0 & $3,250,108$ & \\
\hline DMC-Fossil Fuels & Fossil fuels [kt] & 6150 & $53,052.01$ & $220,949.3$ & 0 & $3,724,362$ & \\
\hline DMC-Minerals & Industrial and construction minerals [kt] & 6150 & $92,565.34$ & $471,696.6$ & 0 & $1.46 \mathrm{e}+07$ & \\
\hline DMC-Ores & Metal ores $[\mathrm{kt}]$ & 6150 & $25,895.54$ & $94,885.44$ & 0 & $1,986,819$ & \\
\hline \multicolumn{8}{|c|}{ Socio-economic variables } \\
\hline Recession & years of GDP decline (value 1 or 0 ) & 5358 & 0.1698 & 0.3755 & 0 & 1 & \multirow{4}{*}{$\begin{array}{l}\text { Based on GDP } \\
\text { growth (World } \\
\text { Bank, 2016) }\end{array}$} \\
\hline Very low growth & years of growth rate between $0-1 \%(1$ or 0$)$ & 5358 & 0.0575 & 0.2328 & 0 & 1 & \\
\hline Low growth & years of growth rate between $1-2 \%(1$ or 0$)$ & 5358 & 0.0752 & 0.2638 & 0 & 1 & \\
\hline Normal growth & years of growth rate between $2-3 \%$ ( 1 or 0$)$ & 5358 & 0.0944 & 0.2925 & 0 & 1 & \\
\hline GDP p.c. & GDP per capita, constant 2005 US\$/cap & 5283 & $8,703.99$ & $13,009.14$ & 111.79 & $87,716.73$ & \multirow{6}{*}{$\begin{array}{l}\text { World Bank } \\
\text { (2016) }\end{array}$} \\
\hline Population & Total population (cap) & 6147 & $3.42 \mathrm{e}+07$ & $1.20 \mathrm{e}+08$ & 84,370 & $1.34 \mathrm{e}+09$ & \\
\hline Urban $\% P$ & Urban population ratio, $\%$ of population & 6150 & 51.14 & 24.59 & 2.85 & 100 & \\
\hline Service \% GDP & Services, etc., value added , $\%$ of GDP & 4845 & 50.65 & 13.53 & 2.96 & 92.84 & \\
\hline Export \% GDP & Exports of goods and services, ratio to GDP & 5253 & 35.90 & 27.66 & 0.18 & 523.46 & \\
\hline Import \% GDP & Imports of goods and services, ratio to GDP & 5261 & 39.27 & 24.75 & 0.12 & 213.48 & \\
\hline Technology $(t-1)$ & Filed patent counts (one-year lagged) & 1986 & 701.24 & 3632.80 & 0 & $52,068.32$ & OECD.Stat \\
\hline$K P$ & Kyoto Protocol $(1$ or 0$)$ & 6150 & 0.32 & 0.47 & 0 & 1 & - \\
\hline
\end{tabular}

Notes: Std. Dev denotes standard deviation. 


\section{Results and discussion}

Between 1970 and 2010, global material use ${ }^{3}$, measured here as DMC, increased by a factor of 2.9, from 23.2 Gigatons (Gt) in 1970 to $68.1 \mathrm{Gt}$ in 2010 . The strongest growth during this period occurred in the use of non-metallic minerals for construction and industrial use (factor 4.7). Consumption of metal ores grew by factor 3.1 and fossil fuels and biomass each grew by factor 2.2. Until 1990, when it was overtaken by construction and industrial minerals, biomass use was the largest of the four material types. The global gross domestic product (GDP) increased by a factor of 3.8 from 14.32 trillion US\$ (2005 constant) in 1970 to 54.47 trillion US\$ in 2010. While these figures suggest similar material and economic growth across the whole time period, a closer look at the development of GDP and DMC from one year to the next allows for the identification of different phases of growth in both macro-indicators.

Between 1970 and 2010, the only phase of global dematerialization (decreasing material consumption) occurred between 1990 and 1992 when DMC decreased from 39.59 to $38.90 \mathrm{Gt} / \mathrm{a}$ coinciding with a noticeable change in global GDP growth (see Fig. 1). This observation corresponds to the findings of Krausmann et al. (2009). During this time, the Gulf War broke out and was followed by the third oil price crisis. The global economic crisis which began in 2007/2008 and resulted in a decline in global GDP between 2008 and 2009, coincided with lower growth of material use compared to the years preceding the crisis. Absolute global material use, however, increased compared to the pre-crisis level (Fig. 1).

\footnotetext{
${ }^{3}$ Here, and throughout the article, we rely on a sample of 150 economies (a list can be found in the Appendix 4) to represent global material use. In 2010 , these 150 economies accounted for $97.41 \%$ of total global material use as estimated by Krausmann et al. (2009).
} 


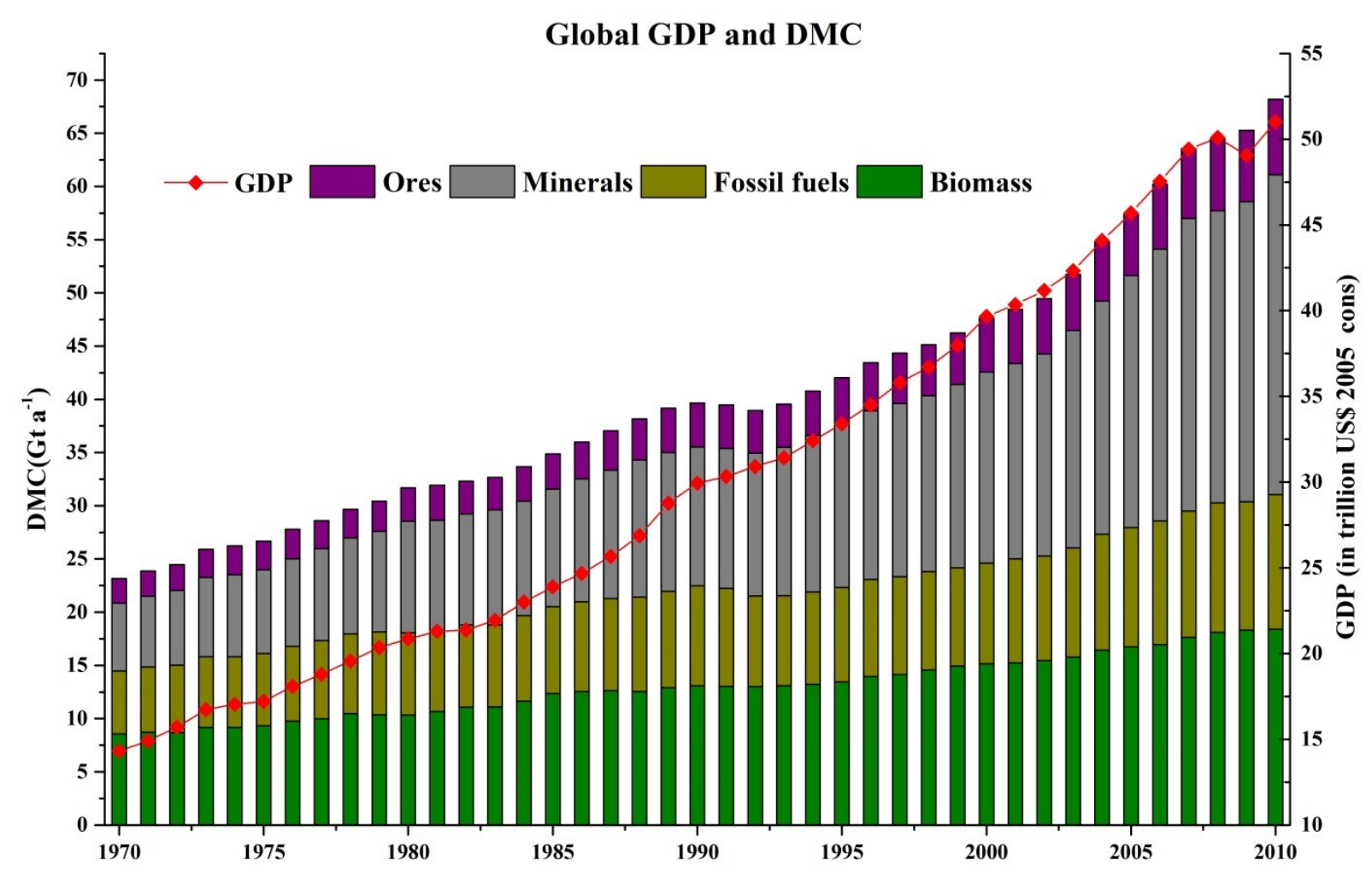

Fig.1. DMC by material types in Gigatonnes per year (Gt $\mathrm{a}^{-1}$, primary y-axis) and total GDP (in trillion constant 2005 US\$; secondary y-axis) for 150 economies. Data sources: UNEP (2016); World Bank (2016).

\subsection{Occurrence of recession across countries and over time}

To empirically examine the relationship between material usage and economic development, we define the years as 'recession' in which negative GDP growth occurs. This definition allows for a binary distinction between years in which recession did or did not occur in any given country. An overview of the frequency of the recession country-years and countries in recession per decade (with the first decade, from 1970 to 1980, spanning 11 years and all other decades spanning ten years) is presented in Table 2. From the first to the second decade, the share of recession country-years (i.e., of the number of countries multiplied by the number of recession years) in total country years (total number of countries multiplied by years in the decade) increased from approximately $15 \%$ to approximately $24 \%$ and dropped thereafter to $19 \%$ and $12 \%$ in the decade from 2001-2010. Another way to consider the data is by the number of countries that spent at least one year in recession during a decade (countries in recession in Table 2): The Democratic Republic of Congo, for example, experienced declining GDP from 1989 to 2001 and is counted as a recession country in the three decades from 1981-1990, from 
1991-2000, and from 2001-2010. The share of recession countries in total countries varied from $61 \%$ in the last decade to $77 \%$ in the second decade (1981-1990).

By both measures, the 1980s and, to a lesser degree, the 1990s, stand out. During the 1980s, known for the debt crisis in Latin America and the world wide credit crunch, among others, $77 \%$ of the countries experienced at least one year of recession and $24 \%$ of the country-years were spent in recession. There was improvement in the 1990s although recession was not uncommon ( $71 \%$ of countries experienced at least one year of recession). This decade encompasses the Gulf War and following oil crisis and the Japanese and Asian financial crisis of 1997/1998. In Thailand, for example, GDP growth dropped to $-10.5 \%$ in 1998 and in Indonesia, the largest economy in Southeast Asia, GDP growth decreased to $-13.1 \%$ in that same year. After 2000, the incidence of recession falls considerably and out of the 180 recession country-years in the last decade, more than half occurred during the last three years from 2008-2010, showing the impacts from the global financial crisis in 2008.

Table. 2. Overview of recession country-years and recession countries by decade between 1970 and 2010.

Source of data: World Bank (2016).

\begin{tabular}{|c|c|c|c|c|c|}
\hline & $1970-1980$ & $1981-1990$ & $1991-2000$ & $2001-2010$ & Trend \\
\hline Recession & & & & & \\
\hline country-years & 170 & 302 & 276 & 180 & \\
\hline $\begin{array}{l}\text { Total country- } \\
\text { years }\end{array}$ & 1163 & 1276 & 1450 & 1466 & \\
\hline $\begin{array}{l}\text { Share of } \\
\text { recession } \\
\text { country-years }\end{array}$ & & & & & \\
\hline (\%) & 14.62 & 23.67 & 19.03 & 12.28 & \\
\hline Countries in & & & & & \\
\hline recession & 75 & 107 & 105 & 91 & \\
\hline Total countries & 110 & 138 & 146 & 149 & \\
\hline $\begin{array}{l}\text { Share of } \\
\text { countries in }\end{array}$ & & & & & \\
\hline recession (\%) & 68.18 & 76.98 & 71.43 & 61.07 & \\
\hline
\end{tabular}




\subsection{Material use under recession in the USA, Germany, Japan, and Brazil}

The country-level recession data presented in Table 2 shows that negative economic growth occurs more frequently throughout the observed time period than the global totals (Fig.1) may have led us to expect. In order to discuss the development of economic growth and material use in conjunction with one another before we turn to the results of our dynamic panel data analysis, we here present growth rates in the underlying indicators for a selection of four countries: the United States of America (U.S.), Germany, Japan, and Brazil. These countries have been chosen, because they are in different phases of their economic development and material use trajectory and all four repeatedly experienced periods of economic recession. During the time period covered investigated, the U.S. was the largest economy worldwide. Germany was the largest economy in Europe and implemented a number of energy- and resource-efficiency policies, the effect of which we are interested to observe. Japan represents the Asian continent and experienced well-known periods of recession, especially during the late 1990s. Brazil, as an emerging economy in Latin America, experienced different development trajectories during this time period, and we are interested to see how it compares to the other three economies which experienced their industrial take-off phases earlier. Because of their size, China and India are often singled out as case study countries. However, these two countries almost have no experience of GDP downscaling over the past four decades, thus we will not individually discuss them here. The development of GDP and DMC growth rates for China and India and two more examples from highly industrialized countries (Italy and UK) are shown in Appendix 3.

The U.S. experienced periods of negative GDP growth from 1973-74, 1981-82, 1990-91, and 2007-09 (Fig.2a). Each of these periods is also marked by decreasing DMC, i.e., by dematerialization during periods of recession. DMC also decreased from 1994-95 and 2001-02, when GDP growth rates were $2.72 \%$ (within the normal growth definition) and $0.95 \%$ (within our very low growth definition) respectively.

Stagnation in DMC growth or dematerialization in Germany (Fig.2b) mostly coincided with GDP growth, although recessions (with dematerialization) did occur 1974-75, 1981-82, 1992-93, 2002-03 and 2008-09. Out of the 41-year period, 21 years fell into one of our low 
growth definitions with GDP growth between 0 and 3\%. DMC declined from 1994 to 1998 with an average annual GDP growth rate of $1.71 \%$, providing an example of dematerialization under low growth conditions.

Japan experienced negative GDP growth from 1973-74, 1997-99 and 2007-09. During all these periods, DMC also declined (Fig.2c). Dematerialization under low growth rates as it occurred in Germany in the 1990s, occurred in Japan in the first years of the $21^{\text {st }}$ century. From 2000-05, DMC decreased by $9.7 \%$ while GDP grew at an average of $1.38 \%$ per year. During these phases, Japan and Germany achieved what is referred to as absolute decoupling of material use and economic growth (UNEP, 2011).

Compared to the other three countries, Brazil was on a DMC growth trajectory during the 41-year period studied here (Fig.2d). This is a trait it shares with other large, emerging economies such as India and China. Nonetheless, (short) phases of low DMC growth or even dematerialization did occur: For example, from 1980-81, both DMC and GDP declined. However, in Brazil, low growth of GDP also coincided with rising material consumption. Between 1997 and 1998, for example, GDP growth (at 0.04\%) fell into our very low growth definition while DMC increased by $2.48 \%$.

a

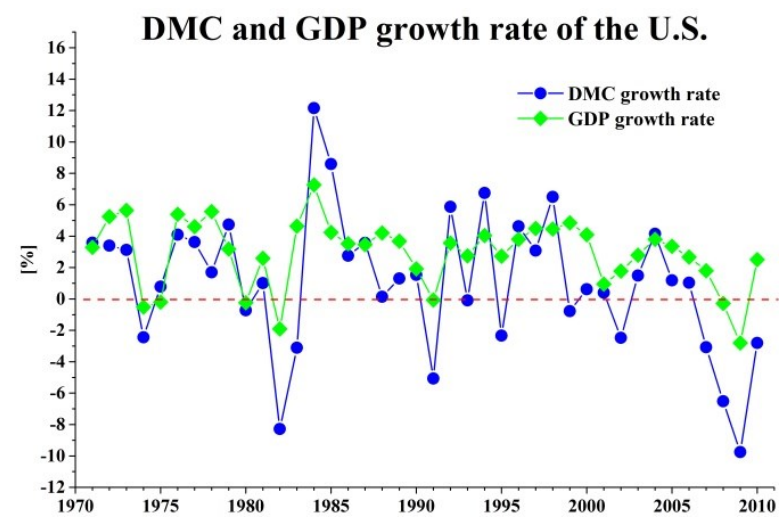

c b

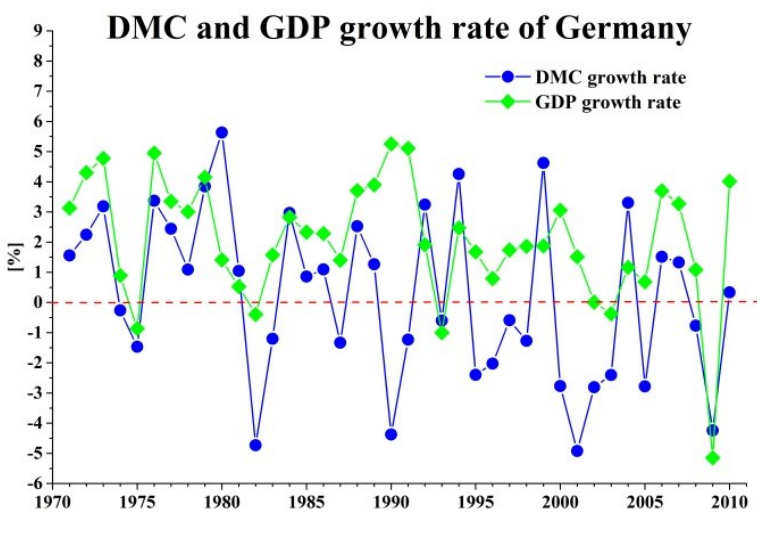

d 

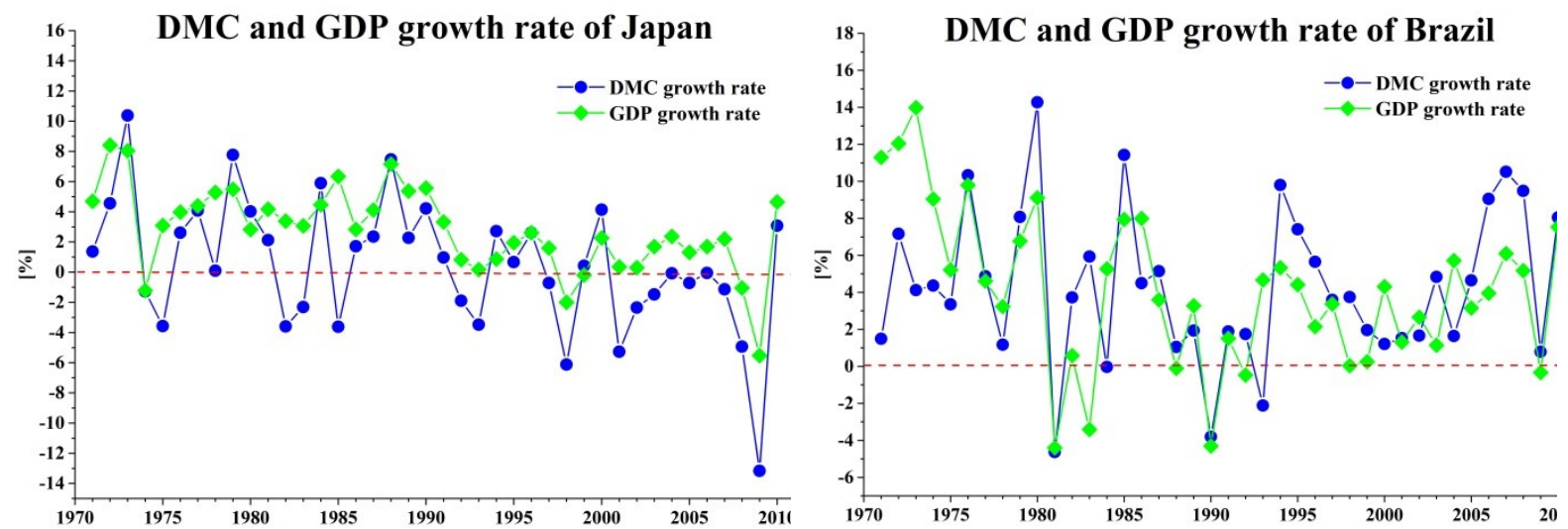

Fig.2. Gross domestic product (GDP) and domestic material consumption (DMC = domestic extraction plus imports minus exports) growth rates in the United States of America (U.S.), Germany, Japan, and Brazil during 1970-2010. Please note the differences in scaling of the y-axis. Data sources: UNEP (2016a), World Bank (2016).

\subsection{Impacts of recession and low GDP growth on material use}

We tested for stationarity of the panel data by applying the panel unit root test (see Appendix 1, Table 1A). An overview of the panel regression results we obtained for the effects of recession and low GDP growth on total DMC is presented in Table 3. We separately studied four models with regard to recession or low GDP growth: In the recession model (results in the first column), the dummy variable in the regression model took on the value 1 if GDP growth was negative. In the very low growth model (results in the second column), the dummy variable took on the value of 1 if GDP growth was between 0 and 1\%. For the low growth model (third column), GDP growth between 1 and $2 \%$ was decisive in terms of the dummy variable and for the normal growth model (fourth column), GDP grew between 2 and 3\% for the dummy variable to take on the value 1 . As expected, $\operatorname{AR}(1), A R(2)$ and the Sargan test confirmed the credibility of the results.

We find that the occurrence of recession is significantly and negatively correlated with DMC. Very low growth is less significantly but also negatively correlated with DMC. For low growth, the significance is even lower and for normal growth, we no longer obtain a significant correlation with DMC. Overall, the higher GDP growth was, the less significant we found the correlation with DMC to be. Because we studied a log-log model (see section 2), the regression coefficient corresponds to the elasticity: In recession years, DMC decreased by $4.9 \%$ on average while during very low growth years, it decreased by $3.9 \%$ and by $2.9 \%$ for low growth. We have 
furthermore separately tested the relationship in a group of countries under recession or low GDP growth $(<1 \%)$ for material use. We found negative correlations both at $1 \%$ significance levels, indicating that the effects of low growth conditions cannot be distinguished under this classification; while the inclusion of countries with higher growth rates ( $<2$ and $<3 \%$ ) generated similar results and thus did not add further insights.

Out of the eight socio-economic control variables, only half show significant correlation with DMC. Per capita GDP (GDP p.c.) has positive correlations with DMC under all four recession and low growth models at 5\% and 10\% significance levels. This corroborates the finding of previous studies that income is a driver of DMC growth, regardless of the current phase of economic growth that a country is in (Steinberger et al., 2013, 2010). Population is also positively correlated with DMC under all four models at a $1 \%$ significance level: More people use more material, even if the economy is in recession. Urban population which we included as a proxy for the share of the population living under the industrial mode is also positively correlated with $\mathrm{DMC}$ at a $5 \%$ significance level. This result corresponds to the expectation that the typical industrial metabolic profile is characterized by high and approximately equivalent shares of biomass, fossil fuel, and construction mineral consumption, as compared to a subsistence mode based more strongly on agricultural activity (FischerKowalski and Schaffartzik, 2015). The share of the services sector in GDP reflects economic structure with a higher share indicating a dominance of economic activities with less direct material intensity. Studies on the material footprint, i.e., on an indicator of material use which allocates material extraction, no matter where in the world it occurs to country of final demand for goods and services which required this material in their production, have highlighted that even highly industrialized economies with a high share of the tertiary sector in their GDP continue to rely indirectly on material extraction in the primary sectors of other countries (Wiedmann et al., 2015). At a 5\% significance level, the share of services in GDP was negatively correlated with DMC. Under economic recession and all three low growth models, countries in which the services sectors played a more important role were more likely to experience dematerialization. Out of the four economies we presented as examples (Fig.2), Germany and Japan are both characterized by high shares of the tertiary sector in GDP (69\% 
and $72 \%$, respectively, in 2015) (World Bank, 2016). This socio-economic variable forms part of the explanation as to why material use in these two countries decreased so strongly during periods of recession. In economies with a high share of the tertiary sector in GDP, recession has a comparatively strong effect on material-intensive activities like construction and primary extraction of building materials (and metal ores where this activity exists) which are responsible for a large share of DMC. In these economies (which have accumulated a high level of manufactured capital in infrastructures and buildings), vulnerability of the physical economy to economic shocks is high, in spite of the monetary dominance of the less material-intensive tertiary sector. No significant relationships appeared for the share of exports and imports of GDP in this panel. This was to be expected because the material use variable we studied (DMC) includes the balance of trade flows but does not (without further information on trade flows) allow for the distinction between export- or import-dependent countries. With regard to the Kyoto Protocol indicator and in light of previous research which showed its correlation to carbon dioxide emissions, this same effect cannot be replicated for total material use but may be relevant in our results of DMC by material category which we present in Table 4. 
Table. 3. Panel regression results under recession and three low growth conditions.

\begin{tabular}{|c|c|c|c|c|c|}
\hline \multirow[t]{2}{*}{ Variable } & & \multicolumn{4}{|c|}{ Model } \\
\hline & & $\begin{array}{l}\text { DMC under } \\
\text { recession }\end{array}$ & $\begin{array}{l}\text { DMC under } \\
\text { very low growth }\end{array}$ & $\begin{array}{l}\text { DMC under } \\
\text { low growth }\end{array}$ & $\begin{array}{l}\text { DMC under } \\
\text { normal growth }\end{array}$ \\
\hline $\begin{array}{c}\text { Time-lagged } \\
\text { variable }\end{array}$ & $D M C(t-1)$ & $\begin{array}{c}0.9256 * * * \\
(0.008)\end{array}$ & $\begin{array}{c}0.9298 * * * \\
(0.008)\end{array}$ & $\begin{array}{c}0.9168 * * * \\
(0.008)\end{array}$ & $\begin{array}{c}0.9230 * * * \\
(0.008)\end{array}$ \\
\hline Recesion & $<0 \%$ & $\begin{array}{c}-0.0487 * * * \\
(0.014)\end{array}$ & & & \\
\hline $\begin{array}{l}\text { Very low } \\
\text { growth }\end{array}$ & $0-1 \%$ & & $\begin{array}{c}-0.0392 * * \\
(0.020)\end{array}$ & & \\
\hline Low growth & $1-2 \%$ & & & $\begin{array}{c}-0.0291 * \\
(0.016)\end{array}$ & \\
\hline Normal growth & $2-3 \%$ & & & & $\begin{array}{l}-0.0242 \\
(0.015)\end{array}$ \\
\hline \multirow{10}{*}{$\begin{array}{c}\text { Contral } \\
\text { variables }\end{array}$} & GDP p.c. & $\begin{array}{l}0.0180^{*} \\
(0.009)\end{array}$ & $\begin{array}{c}0.0134 * * \\
(0.009)\end{array}$ & $\begin{array}{c}0.0223 * * \\
(0.009)\end{array}$ & $\begin{array}{c}0.0203 * * \\
(0.010)\end{array}$ \\
\hline & Population & $\begin{array}{c}0.0698^{* * *} * \\
(0.009)\end{array}$ & $\begin{array}{c}0.0651 * * * \\
(0.009)\end{array}$ & $\begin{array}{c}0.0788 * * * \\
(0.009)\end{array}$ & $\begin{array}{c}0.0732 * * * \\
(0.009)\end{array}$ \\
\hline & $\begin{array}{l}\text { Urban\% } P \\
\text { Service\% } \\
\quad G D P\end{array}$ & $\begin{array}{c}0.0412 * * \\
(0.018) \\
-0.0816^{* *} \\
(0.033)\end{array}$ & $\begin{array}{c}0.0381 * * \\
(0.018) \\
-0.0676 * * \\
(0.033)\end{array}$ & $\begin{array}{c}0.0384 * * \\
(0.017) \\
-0.0755 * * \\
(0.033)\end{array}$ & $\begin{array}{c}0.0364 * * \\
(0.018) \\
-0.0746 * * \\
(0.033)\end{array}$ \\
\hline & Export\% & 0.0105 & 0.0115 & 0.0062 & 0.0059 \\
\hline & $G D P$ & $(0.023)$ & $(0.023)$ & $(0.023)$ & $(0.023)$ \\
\hline & Import\% & -0.0087 & -0.0088 & -0.0046 & -0.0029 \\
\hline & $G D P$ & $(0.025)$ & $(0.025)$ & $(0.025)$ & $(0.025)$ \\
\hline & Technology & 0.0001 & 0.0011 & 0.0001 & -0.0001 \\
\hline & $(t-1)$ & $(0.003)$ & $(0.003)$ & $(0.003)$ & $(0.004)$ \\
\hline & $K P$ & $\begin{array}{l}-0.0056 \\
(0.012)\end{array}$ & $\begin{array}{l}-0.0076 \\
(0.012)\end{array}$ & $\begin{array}{l}-0.0027 \\
(0.012)\end{array}$ & $\begin{array}{l}-0.0042 \\
(0.012)\end{array}$ \\
\hline Constant & & $\begin{array}{l}-0.2328 \\
(0.210)\end{array}$ & $\begin{array}{l}-0.2183 \\
(0.209)\end{array}$ & $\begin{array}{l}-0.3335 \\
(0.210)\end{array}$ & $\begin{array}{l}-0.2959 \\
(0.210)\end{array}$ \\
\hline Observations & & 1781 & 1781 & 1781 & 1781 \\
\hline$A R(1)$ & & 0.000 & 0.000 & 0.000 & 0.000 \\
\hline$A R(2)$ & & 0.912 & 0.944 & 0.965 & 0.994 \\
\hline Sargan P-value & & 0.844 & 0.871 & 0.865 & 0.849 \\
\hline
\end{tabular}

Note: Variables were logarithmized except for the dummy variables; standard errors in parentheses; *, ** and ${ }^{* * *}$ denote significant $\mathrm{p}$-values at $10 \%, 5 \%$ and $1 \%$ levels, respectively. 


\subsection{Impacts of recession and low GDP growth on material use categories}

In addition to analyzing the effect of recession and low growth on material use, we split the dependent variable (DMC) into four material categories - biomass, fossil fuels, non-metallic minerals (industrial and construction minerals), and ores - in order to detect whether material use by categories is affected to the same degree by recession or low growth as total DMC. Previous research has indicated that determinants of these specific material groups differ, mostly between biomass and the other material categories (Steinberger et al., 2013).

The effects of economic recession or very low growth on DMC in the four material categories are shown in Table 4. We only show the result of recession and very low growth as no further insights are gained from including more results (for the effects of economic growth $>1 \%$ see Appendix 2, Table 2A). Recession is significantly (at the 1\% level) and negatively correlated with material use of fossil fuels, of industrial and construction minerals and of metal ores. Biomass is the only material category for which no significant correlation could be detected. This reflects that biomass used for human nutrition and animal feed is highly prioritized across countries, even in times of economic recession as was suggested by Krausmann et al. (2009) in assessing the development of global material use levels. In contrast, the impact of recession appears to be especially strong on non-metallic minerals: During one year of recession, material use in this category decreased by an average of $16 \%$. This change is mainly caused by a decline in use of construction minerals (which are minerals used in bulk for construction purposes such as limestone, sand and gravel), as the use of these materials is closely tied to the economic activity in the material intensive construction sector (Giang and Sui Pheng, 2011). Although Keynesian stabilization policy suggests infrastructure investments in times of recession, this may occur with a certain time lag after the initial recession periods and an increase of material use along with infrastructure investments usually emerges in subsequent growth periods (Wigren and Wilhelmsson, 2007).

Use of metal ores, in which ferrous ores required for the production of steel play an important role, decreased by an average of $15 \%$ during one year of recession. This resembles the pattern found for non-metallic minerals and is related to the high share of steel and other metals used in construction and often in combination with non-metallic minerals (e.g., in 
reinforced concrete) (Allwood et al., 2012). The interlinkage of the material-intensive construction sector and economic growth/recession clearly require more attention in the discussion of dematerialization. The impact of recession on fossil fuel use was noticeable but less pronounced than for metallic and non-metallic minerals: During one year of recession, their use decreased by an average of 5\%. This suggests that the major share of activity which requires fossil energy input continues even in times of recession. This interpretation is supported by the positive correlation between fossil fuel consumption and per capita income which we detected via the control variables.

In the very low growth model, significant (at the $1 \%$ level) negative correlations could only be detected for industrial and construction minerals and for metal ores, illustrating that consumption of these materials could decrease very noticeably, even if positive GDP growth occurred. Although at very low levels of GDP growth, this was the most important potential decoupling effect which we observed.

Under recession and very low growth, we found significant (1\%) positive correlation between population and fossil energy and metal ores consumption. A remarkable effect with regard to population is the significant $(5 \%)$ positive correlation between the urban share of the population and biomass consumption during recession and the very low growth years. Under the industrial mode (for which we use the share of urban population as a proxy), an important share of biomass consumption is for human consumption, directly or indirectly (e.g., as animal fodder) which appears not to be negatively impacted by recession or very low growth. This potential causal link is not yet well-understood and merits further investigation. The material categories of industrial and construction minerals and metal ores are the only ones for which the trade variables exhibit any significance. Especially noteworthy is the significant (1 and 5\%) negative correlation between the ratio of imports to GDP (Import \% GDP) and consumption of ores under the recession and the very low growth model: Comparatively high spending on imports may suggest low levels of domestic production and possibly less resilience in the face of recession or very low growth.

Non-metallic minerals and metals used in large quantities in construction (such as steel) and other material-intensive industries appear to be more sensitive to economic fluctuations 
than the throughput-dominated flows of biomass and fossil fuels. This may relate to the fact that fossil materials (fuel) are essential to the functioning of the modern, industrial society and biomass (food and feed) is irreplaceable in its role of sustaining the human population (with specific dietary patterns) so that the use of these two material categories is less strongly (and/or not immediately) affected by economic recession. In contrast, minerals and metals are used in material-intensive construction and industry sectors which are immediately vulnerable to recession. 
Table 4. Panel regression results of the effects of recession/very low growth on four material categories of DMC.

\begin{tabular}{|c|c|c|c|c|c|c|c|c|c|}
\hline \multirow{3}{*}{\multicolumn{2}{|c|}{ Variables }} & \multicolumn{8}{|c|}{ Model } \\
\hline & & \multicolumn{2}{|c|}{ DMC-Biomass } & \multicolumn{2}{|c|}{ DMC-Fossil Fuels } & \multicolumn{2}{|c|}{ DMC-Minerals } & \multicolumn{2}{|c|}{ DMC-Ores } \\
\hline & & $\begin{array}{c}\text { Under } \\
\text { recession }\end{array}$ & $\begin{array}{l}\text { Under very } \\
\text { low growth }\end{array}$ & $\begin{array}{c}\text { Under } \\
\text { recession }\end{array}$ & $\begin{array}{l}\text { Under very } \\
\text { low growth }\end{array}$ & $\begin{array}{c}\text { Under } \\
\text { recession }\end{array}$ & $\begin{array}{l}\text { Under very } \\
\text { low growth }\end{array}$ & $\begin{array}{c}\text { Under } \\
\text { recession }\end{array}$ & $\begin{array}{l}\text { Under very } \\
\text { low growth }\end{array}$ \\
\hline $\begin{array}{c}\text { Time-lagged } \\
\text { variable }\end{array}$ & $D M C(t-1)$ & $\begin{array}{c}0.9344 * * * \\
(0.040) \\
\end{array}$ & $\begin{array}{c}0.9341 * * * \\
(0.041) \\
\end{array}$ & $\begin{array}{c}0.9467 * * * \\
(0.020) \\
\end{array}$ & $\begin{array}{c}0.9527 * * * \\
(0.019) \\
\end{array}$ & $\begin{array}{c}0.9692 * * * \\
(0.018) \\
\end{array}$ & $\begin{array}{c}0.9670 * * * \\
(0.019) \\
\end{array}$ & $\begin{array}{c}0.9376 * * * \\
(0.015) \\
\end{array}$ & $\begin{array}{c}0.9285^{* * * *} \\
(0.017) \\
\end{array}$ \\
\hline Recession & $<0 \%$ & $\begin{array}{l}-0.0056 \\
(0.022) \\
\end{array}$ & & $\begin{array}{c}-0.0526 * * * \\
(0.015) \\
\end{array}$ & & $\begin{array}{c}-0.1628 * * * \\
(0.018) \\
\end{array}$ & & $\begin{array}{c}-0.1571 * * * \\
(0.034) \\
\end{array}$ & \\
\hline $\begin{array}{l}\text { Very low } \\
\text { growth }\end{array}$ & $0-1 \%$ & & $\begin{array}{r}-0.0323 \\
(0.027) \\
\end{array}$ & & $\begin{array}{l}0.0163 \\
(0.013) \\
\end{array}$ & & $\begin{array}{c}-0.0657 * * * \\
(0.017) \\
\end{array}$ & & $\begin{array}{c}-0.1152 * * * \\
(0.039) \\
\end{array}$ \\
\hline \multirow{8}{*}{$\begin{array}{c}\text { Contral } \\
\text { variables }\end{array}$} & GDP p.c. & $\begin{array}{l}-0.0205 \\
(0.013)\end{array}$ & $\begin{array}{l}-0.0223 \\
(0.014)\end{array}$ & $\begin{array}{c}0.0337 * * \\
(0.014)\end{array}$ & $\begin{array}{c}0.0346 * * \\
(0.014)\end{array}$ & $\begin{array}{l}0.0131 \\
(0.015)\end{array}$ & $\begin{array}{l}0.0270 * \\
(0.016)\end{array}$ & $\begin{array}{c}-0.0287 * * \\
(0.015)\end{array}$ & $\begin{array}{l}-0.0212 \\
(0.017)\end{array}$ \\
\hline & Population & $\begin{array}{l}0.0327 \\
(0.032)\end{array}$ & $\begin{array}{l}0.0319 \\
(0.032)\end{array}$ & $\begin{array}{c}0.0637 * * * \\
(0.023)\end{array}$ & $\begin{array}{c}0.0603 * * * \\
(0.022)\end{array}$ & $\begin{array}{l}0.0322 \\
(0.021)\end{array}$ & $\begin{array}{l}0.0402 * \\
(0.022)\end{array}$ & $\begin{array}{c}0.0450 * * * \\
(0.018)\end{array}$ & $\begin{array}{c}0.0528 * * * \\
(0.020)\end{array}$ \\
\hline & Urban\% $\%$ & $\begin{array}{c}0.0602 * * \\
(0.026)\end{array}$ & $\begin{array}{c}0.0614 * * \\
(0.029)\end{array}$ & $\begin{array}{l}0.0167 \\
(0.022)\end{array}$ & $\begin{array}{l}0.0067 \\
(0.019)\end{array}$ & $\begin{array}{l}0.0048 \\
(0.014)\end{array}$ & $\begin{array}{l}-0.0192 \\
(0.013)\end{array}$ & $\begin{array}{c}0.1000 * * * \\
(0.032)\end{array}$ & $\begin{array}{c}0.0927 * * \\
(0.039)\end{array}$ \\
\hline & $\begin{array}{c}\text { Service\% } \\
\text { GDP }\end{array}$ & $\begin{array}{c}-0.2808^{*} \\
(0.017)\end{array}$ & $\begin{array}{c}-0.2772 * \\
(0.168)\end{array}$ & $\begin{array}{l}-0.0194 \\
(0.036)\end{array}$ & $\begin{array}{l}-0.0097 \\
(0.034)\end{array}$ & $\begin{array}{l}-0.0095 \\
(0.057)\end{array}$ & $\begin{array}{l}-0.0068 \\
(0.064)\end{array}$ & $\begin{array}{l}0.0138 \\
(0.090)\end{array}$ & $\begin{array}{l}0.0071 \\
(0.092)\end{array}$ \\
\hline & $\begin{array}{c}\text { Export\% } \\
G D P\end{array}$ & $\begin{array}{l}-0.0635 \\
(0.053)\end{array}$ & $\begin{array}{l}-0.0621 \\
(0.050)\end{array}$ & $\begin{array}{l}0.0158 \\
(0.021)\end{array}$ & $\begin{array}{l}0.0094 \\
(0.020)\end{array}$ & $\begin{array}{l}-0.0212 \\
(0.021)\end{array}$ & $\begin{array}{c}-0.0449 * \\
(0.024)\end{array}$ & $\begin{array}{c}0.1045 * * \\
(0.049)\end{array}$ & $\begin{array}{c}0.0906^{*} \\
(0.056)\end{array}$ \\
\hline & $\begin{array}{c}\text { Import\% } \\
G D P\end{array}$ & $\begin{array}{l}0.0161 \\
(0.036)\end{array}$ & $\begin{array}{l}0.0129 \\
(0.035)\end{array}$ & $\begin{array}{l}0.0122 \\
(0.024)\end{array}$ & $\begin{array}{l}0.0204 \\
(0.023)\end{array}$ & $\begin{array}{l}0.0247 \\
(0.024)\end{array}$ & $\begin{array}{c}0.0550 * * \\
(0.026)\end{array}$ & $\begin{array}{c}-0.1467 * * * \\
(0.053)\end{array}$ & $\begin{array}{c}-0.1397 * * \\
(0.061)\end{array}$ \\
\hline & $\begin{array}{c}\text { Technology } \\
(t-1)\end{array}$ & $\begin{array}{c}0.0175^{*} \\
(0.010)\end{array}$ & $\begin{array}{l}0.0181 * \\
(0.011)\end{array}$ & $\begin{array}{c}-0.0046^{*} \\
(0.003)\end{array}$ & $\begin{array}{c}-0.0062 * * \\
(0.003)\end{array}$ & $\begin{array}{l}-0.0049 \\
(0.003)\end{array}$ & $\begin{array}{c}-0.0076^{* *} \\
(0.003)\end{array}$ & $\begin{array}{l}0.0117 * \\
(0.007)\end{array}$ & $\begin{array}{c}0.0123 * \\
(0.007)\end{array}$ \\
\hline & $K P$ & $\begin{array}{l}-0.0108 \\
(0.014) \\
\end{array}$ & $\begin{array}{l}-0.0119 \\
(0.013) \\
\end{array}$ & $\begin{array}{l}-0.0087 \\
(0.009) \\
\end{array}$ & $\begin{array}{r}-0.0048 \\
(0.009) \\
\end{array}$ & $\begin{array}{r}0.0087 \\
(0.010) \\
\end{array}$ & $\begin{array}{l}0.0171 \\
(0.011) \\
\end{array}$ & $\begin{array}{l}-0.0311 \\
(0.029) \\
\end{array}$ & $\begin{array}{l}-0.0256 \\
(0.031) \\
\end{array}$ \\
\hline Constant & & 1.3670 & 1.3859 & $-0.8525 * *$ & $-0.8747 * * *$ & -0.2466 & -0.4273 & -0.2249 & -0.2771 \\
\hline
\end{tabular}




\begin{tabular}{ccccccccc}
\hline & $(0.967)$ & $(0.993)$ & $(0.344)$ & $(0.335)$ & $(0.388)$ & $(0.446)$ & $(0.532)$ & $(0.590)$ \\
Observations & 1770 & 1770 & 1719 & 1719 & 1770 & 1770 & 1681 & 1681 \\
\hline AR (1) & 0.017 & 0.016 & 0.072 & 0.074 & 0.001 & 0.000 & 0.000 & 0.000 \\
AR (2) & 0.568 & 0.584 & 0.179 & 0.200 & 0.604 & 0.855 & 0.669 \\
Sargan P-value & 0.998 & 0.995 & 0.994 & 0.991 & 0.230 & 0.017 & 0.984 & 0.977 \\
\hline
\end{tabular}

Note: We only show the result of recession and very low growth as no new insights are gained from the results for low and normal growth, further results are shown in the Appendix 2, Table 2A. Variables were logarithmized except for the dummy variables; standard errors in parentheses; $* * *$ and $* * *$ denote significant p-values at $10 \%$, $5 \%$ and $1 \%$ levels, respectively. 


\section{Conclusions and outlook}

Dematerialization, the reduction of absolute levels of material resource consumption, is a prerequisite to tackling some of the most pressing environmental issues of our time and to achieving a sustainability transformation. Using a dynamic panel data model to analyze the relationships between material flow and socioeconomic indicators for 150 economies from 1970 to 2010, we found that globally, dematerialization coincided with periods of economic recession or very low growth which occurred most frequently and in the largest number of countries during the 1980s and the 1990s. In the early 1990s, the high number of countries in recession can be linked to a decline in global material use. In the four important economies (the U.S., Germany, Japan, and Brazil) which we used as in depth case studies, periods of economic recession were always also periods of dematerialization. In contrast, GDP growth, even at comparatively low levels between 2 and 3\%, made the occurrence of dematerialization very unlikely. Where dematerialization did occur (during periods of recession or low growth), not all material categories were equally impacted: While the use of industrial and construction minerals and metal ores was most likely to decrease, fossil fuels and biomass were less likely to react to these economic changes.

At high levels of population, affluence, and urbanization, material use was likely to remain high (and grow) even during times of economic recession or low growth levels. The higher the share of the service sector was in GDP, the more likely dematerialization was to occur.

Our results highlight an urgent need to rethink resource policies internationally, especially with regard to much-needed absolute reductions in resource use. Politically (and also socio-economically) attractive goals in other policy areas (including high and growing levels of wealth and access to modern energy) have yet to be disconnected from growing material resource use. The prevalence of the tertiary over the primary sector, which was found to have a positive effect on dematerialization, can only be implemented internationally if overall material resource use levels are reduced: Even in highly industrialized economies in which services contribute a large share of GDP, 
the material footprint (i.e., material use, no matter where in the world it occurs, required for final consumption of goods and services) has continued to grow (Wiedmann et al., 2015). The material use of these countries requires material extraction elsewhere.

Considering the high level of current global material resource use and its continuous growth from 1970 to 2010 , it is surprising how many countries intermittently experienced periods of dematerialization. We did not, however, find examples of such dematerialization occurring in a sustainable manner. Instead, evidence for long-term changes in resource use patterns is lacking: Following periods of economic recession and reduction in material use, the material use indicator often quickly returned to previous levels.

In this study we could show that dematerialization typically occurs under conditions of low or negative economic growth. This is only a first step, however. Further research is needed to investigate the long-term effects of recessions and accelerated growth after recession periods on resource use and to analyze if continuous dematerialization could be achieved under conditions of low economic growth and which levels of growth would still permit dematerialization. In this context it will be of particular importance to take differences between high and low income countries in the relation of low growth and dematerialization into account, which we did not address in this study, and to address trade-offs between long-term dematerialization and economic and social consequences in these countries. By studying countries which are able to maintain low levels of material use and resume economic growth, we may gain insights on ingredients of a sustainability transition. We propose to study in greater detail the level of renewed GDP growth at which countries return to their pre-recession patterns of material use, to consider the impacts of policies to counteract recession (e.g. Keynesian investments in infrastructure, austerity measures, etc.) on material use, and to consider the country-specific socio-economic factors which further explain the observed relation between material use and economic growth patterns. The pivotal role of accumulated material stock (in buildings, infrastructures, and durable products) in the early industrializers must constitute a particular focus: Our study has shown that 
construction minerals strongly contribute to dematerialization during recession. Simultaneously, the investment of capital in infrastructure is often promoted to avoid or curb recession. Better understanding the interlinkage of the material-intensive construction sector and recession is imperative to assessing the impact of such policies on resource use. Recession is clearly not an economically or socially sustainable pathway to curb environmental impacts. It might illustrate, however, lower levels of material use at which societies can continue to function.

\section{References}

Aichele, R., Felbermayr, G., 2014. Kyoto and Carbon Leakage: An Empirical Analysis of the Carbon Content of Bilateral Trade. Rev. Econ. Stat. 96, 402-417. doi:10.1162/REST

Akenji, L., Bengtsson, M., Bleischwitz, R., Tukker, A., Schandl, H., 2016. Ossified materialism: introduction to the special volume on absolute reductions in materials throughput and emissions. J. Clean. Prod. doi:10.1016/j.jclepro.2016.03.071

Alfredsson, E.C., Malmaeus, J.M., 2017. Prospects for economic growth in the 21 st century - a survey covering mainstream, heterodox and scientifically oriented perspectives. Econ. Issues 22, 65-88.

Allwood, J.M., Cullen, J.M., Carruth, M.A., Cooper, D.R., McBrien, M., Milford, R.L., Moynihan, M., Patel, A.C.H., 2012. Sustainable Materials: With both eyes open. UIT, Cambridge.

Arellano, M., Bond, S., 1991. Some Tests of Specification for Panel Data: Monte Carlo Evidence and an Application to Employment Equations. Rev. Econ. Stud. 58, 277-297. doi:10.2307/2297968

Barro, R.J., Ursúa, J.F., 2008. Macroeconomic Crises since 1870. Brookings Pap. Econ. Act. 2008, 255-350. doi:10.1353/eca.0.0000

Bayer, P., Dolan, L., Urpelainen, J., 2013. Global patterns of renewable energy innovation, 1990-2009. Energy Sustain. Dev. 17, 288-295. 
doi:10.1016/j.esd.2013.02.003

Behrens, A., Giljum, S., Kovanda, J., Niza, S., 2007. The material basis of the global economy Worldwide patterns of natural resource extraction and their implications for sustainable resource use policies. Ecol. Econ. 64, 444-453. doi:10.1016/j.ecolecon.2007.02.034

Bergoeing, R., Kehoe, P.J., Kehoe, T.J., Soto, R., 2002. A Decade Lost and Found : Mexico and Chile in the 1980s. Rev. Econ. Dyn. 5, 166-205.

Blundell, R., Bond, S., 1998. Initial conditions and moment restrictions in dynamic panel data models. J. Econom. 87, 115-143. doi:10.1016/S0304-4076(98)000098

Breuer, J.B., McDermott, J., 2013. Economic depression in the world. J. Macroecon. 38, 227-242. doi:10.1016/j.jmacro.2013.07.003

Bringezu, S., Schütz, H., Steger, S., Baudisch, J., 2004. International comparison of resource use and its relation to economic growth: The development of total material requirement, direct material inputs and hidden flows and the structure of TMR. Ecol. Econ. 51, 97-124. doi:10.1016/j.ecolecon.2004.04.010

Burke, P.J., Shahiduzzaman, M., Stern, D.I., 2015. Carbon dioxide emissions in the short run: The rate and sources of economic growth matter. Glob. Environ. Chang. doi:10.1016/j.gloenvcha.2015.04.012

Cheon, A., Urpelainen, J., 2012. Oil prices and energy technology innovation : An empirical analysis. Glob. Environ. Chang. 22, 407-417. doi:10.1016/j.gloenvcha.2011.12.001

Chiu, A.S.F., Dong, L., Geng, Y., Rapera, C., Tan, E., 2017. Philippine resource efficiency in Asian context: status, trends and driving forces of Philippine material flows from 1980-2008. J. Clean. Prod. 153, 63-73. doi:10.1016/j.jclepro.2017.03.158

Claessens, S., Kose, M.A., Terrones, M.E., 2009. What happens during recessions, crunches and busts? Econ. Policy 653-700. doi:10.1002/cjoc.2013xxxxx.

Cole, H.L., Ohanian, L.E., 2002. The Great U.K. Depression: A Puzzle and Possible 
Resolution. Rev. Econ. Dyn. 5, 19-44. doi:10.1006/redy.2001.0140

Dong, L., Dai, M., Liang, H., Zhang, N., Mancheri, N., 2017. Material flows and resource productivity in China, South Korea and Japan from 1970 to 2008 : A transitional perspective. J. Clean. Prod. 141, 1164-1177. doi:10.1016/j.jclepro.2016.09.189

Ewijk, S. Van, Stegemann, J.A., 2016. Limitations of the waste hierarchy for achieving absolute reductions in material throughput. J. Clean. Prod. 132, 122128. doi:10.1016/j.jclepro.2014.11.051

Fischer-Kowalski, M., Krausmann, F., Giljum, S., Lutter, S., Mayer, A., Bringezu, S., Moriguchi, Y., Schütz, H., Schandl, H., Weisz, H., 2011. Methodology and Indicators of Economy-wide Material Flow Accounting. J. Ind. Ecol. 15, 855876. doi:10.1111/j.1530-9290.2011.00366.x

Fischer-Kowalski, M., Schaffartzik, A., 2015. Energy availability and energy sources as determinants of societal development in a long-term perspective. MRS Energy Sustain. - A Rev. J. 2. doi:10.1557/mre.2015.2

Fisher, J.D.M., Hornstein, A., 2002. The Role of Real Wages, Productivity, and Fiscal Policy in Germany’s Great Depression 1928-1937. Rev. Econ. Dyn. 5, 100-127. doi:10.1006/redy.2001.0142

Giang, D.T.H., Sui Pheng, L., 2011. Role of construction in economic development: Review of key concepts in the past 40 years. Habitat Int. 35, 118-125. doi:10.1016/j.habitatint.2010.06.003

Giljum, S., Dittrich, M., Lieber, M., Lutter, S., 2014. Global Patterns of Material Flows and their Socio-Economic and Environmental Implications: A MFA Study on All Countries World-Wide from 1980 to 2009. Resources 3, 319-339. doi:10.3390/resources3010319

Hayashi, F., Prescott, E.C., 2002. The 1990s in Japan: A Lost Decade. Rev. Econ. Dyn. 5, 206-235. doi:10.1006/redy.2001.0149

Kehoe, T.J., Prescott, E.C., 2002. Great Depressions of the 20th Century. Rev. Econ. Dyn. 5, 1-18. doi:10.1006/redy.2001.0151 
Krausmann, F., Gingrich, S., Eisenmenger, N., Erb, K.-H., Haberl, H., FischerKowalski, M., 2009. Growth in global materials use, GDP and population during the 20th century. Ecol. Econ. 68, 2696-2705. doi:10.1016/j.ecolecon.2009.05.007

Kydland, F.E., Zarazaga, C.E.J.M., 2002. Argentina`s Lost Decade. Rev. Econ. Dyn. 5, 152-165. doi:10.1006/redy.2001.0145

Malmaeus, J.M., Alfredsson, E.C., 2017. Potential Consequences on the Economy of Low or No Growth - Short and Long Term Perspectives. Ecol. Econ. 134, 57-64. doi:10.1016/j.ecolecon.2016.12.011

Mirabella, N., Rigamonti, L., Scalbi, S., 2013. Life cycle assessment of Information and Communication Technology application : a case study of dematerialization in the Italian Public Administration. J. Clean. Prod. 44, 115-122. doi:10.1016/j.jclepro.2012.10.051

Nguyen, T., Locke, S., Reddy, K., 2014. A dynamic estimation of governance structures and financial performance for Singaporean companies. Econ. Model. 40, 1-11. doi:10.1016/j.econmod.2014.03.013

Reddy, S., Minoiu, C., 2009. Real Income Stagnation of Countries 1960 - 2001 Real Income Stagnation of Countries. J. Dev. Stud. 45.

doi:10.1080/00220380802265249

Rogich, D.G., 1996. Material use, economic growth, and the environment. Nonrenewable Resour. 5, 197-210. doi:10.1007/BF02257435

Roodman, D., 2010. How to do xtabond2: An introduction to difference and system GMM in Stata. Stata J. 10, 288-308.

Russi, D., Gonzalez-Martinez, A.C., Silva-Macher, J.C., Giljum, S., Martínez-Alier, J., Vallejo, M.C., 2008. Material Flows in Latin America. J. Ind. Ecol. 12, 704720. doi:10.1111/j.1530-9290.2008.00074.x

Schaffartzik, A., Mayer, A., Gingrich, S., Eisenmenger, N., Loy, C., Krausmann, F., 2014. The global metabolic transition: Regional patterns and trends of global material flows, 1950-2010. Glob. Environ. Chang. 26, 87-97. 
doi:10.1016/j.gloenvcha.2014.03.013

Schandl, H., Fischer-kowalski, M., West, J., Giljum, S., Dittrich, M., 2017. Global Material Flows and Resource Productivity: Forty Years of Evidence. J. Ind. Ecol. 0,1-12. doi:10.1111/jiec. 12626

Schandl, H., Hatfield-dodds, S., Wiedmann, T., Geschke, A., West, J., Newth, D., Baynes, T., Lenzen, M., Owen, A., 2016. Decoupling global environmental pressure and economic growth: scenarios for energy use, materials use and carbon emissions. J. Clean. Prod. 132, 45-56. doi:10.1016/j.jclepro.2015.06.100

Schumacher, I., 2014. An empirical study of the determinants of green party voting. Ecol. Econ. 105, 306-318. doi:10.1016/j.ecolecon.2014.05.007

Steinberger, J.K., Krausmann, F., Eisenmenger, N., 2010. Global patterns of materials use: A socioeconomic and geophysical analysis. Ecol. Econ. 69, 1148-1158. doi:10.1016/j.ecolecon.2009.12.009

Steinberger, J.K., Krausmann, F., Getzner, M., Schandl, H., West, J., 2013. Development and Dematerialization: An International Study. PLoS One 8, e70385. doi:10.1371/journal.pone.0070385

UNEP, 2016a. Global Material Flows and Resource Productivity: Assessment Report for the UNEP International Resource Panel, United Nations Environment Programme. Paris.

UNEP, 2016b. UNEP Environmental Data Explorer [WWW Document]. UNEP Environ. Data Explor. URL http://geodata.grid.unep.ch/webservices/ (accessed 7.12.16).

UNEP, 2011. Decoupling natural resource use and environmental impacts from economic growth. United Nations Environment Programme, Paris.

Vehmas, J., Luukkanen, J., Kaivo-oja, J., 2007. Linking analyses and environmental Kuznets curves for aggregated material flows in the EU. J. Clean. Prod. 15, 1662-1673. doi:10.1016/j.jclepro.2006.08.010

Version, D., 2011. Entrepreneurial Dynamics in Local Economic Development.

Wiedmann, T.O., Schandl, H., Lenzen, M., Moran, D., Suh, S., West, J., Kanemoto, 
K., 2015. The material footprint of nations. Proc. Natl. Acad. Sci. 112, 62716276. doi:10.1073/pnas.1220362110

Wigren, R., Wilhelmsson, M., 2007. Construction investments and economic growth in Western Europe. J. Policy Model. 29, 439-451.

doi:10.1016/j.jpolmod.2006.10.001

World Bank, 2016. World Development Indicators Database [WWW Document].

URL http://data.worldbank.org/news/new-country-classifications

\section{Acknowledgements}

This work was supported by the State Scholarship Fund from China Scholarship Council (Grant No. 201306240017), the Austrian Science Fund FWF (Project MISO P27590), and the European Union (FP7-Science in Society-2010-1 Project Environmental Justice Organizations, Liabilities and Trade - EJOLT). The authors wish to thank ICREA Professor Giorgos Kallis and Dr. Beatriz Rodríguez-Labajos at ICTAUAB as well as Nesen Ertugrul, Gerda Gieselmann-Hoschek, and Bernhard Hammer at Alpen-Adria University. 
Appendix 1: Panel unit root test

Table 1A displays the results of Fisher's test, considering the unbalanced nature of our panels. The null hypothesis is that all panels have non-stationary time series. Therefore, if the null is rejected in levels, the series is assumed to be $\mathrm{I}(0)$; if the null fails to reject when in levels, but is rejected when in first differences, the series is assumed to be I(1). Results suggest that variables, except for Oil Price and Kyoto Protocol, are I(0).

Table 1A. Results for panel unit root test.

\begin{tabular}{|l|l|l|l|l|}
\hline & \multicolumn{2}{|l|}{ Variables in levels } & \multicolumn{2}{l|}{ Variables in first differences } \\
\hline & Statistic & Prob & Statistic & Prob \\
\hline DMC & 505.6956 & $0.0000^{* * *}$ & 2390.2648 & $0.0000^{* * *}$ \\
\hline Recession & 1475.0729 & $0.0000^{* * *}$ & 4924.6855 & $0.0000^{* * *}$ \\
\hline GDP p.c. & 344.8513 & $0.0220^{* *}$ & 1536.7189 & $0.0000^{* * *}$ \\
\hline Population & 722.8675 & $0.0000^{* * *}$ & 1911.4442 & $0.0000^{* * *}$ \\
\hline Urban \% P & 770.5793 & $0.0000^{* * *}$ & 362.9975 & $0.0074^{* * *}$ \\
\hline Service\% GDP & 429.4552 & $0.0000^{* * *}$ & 2035.1150 & $0.0000^{* * *}$ \\
\hline Export\% GDP & 538.8598 & $0.0000^{* * *}$ & 2369.1151 & $0.0000^{* * *}$ \\
\hline Import\% GDP & 545.4014 & $0.0000^{* * *}$ & 2348.4349 & $0.0000^{* * *}$ \\
\hline Technology (t-1) & 319.7890 & $0.0000^{* * *}$ & 1305.6822 & $0.0000^{* * *}$ \\
\hline Oil Price & 51.2509 & 1.0000 & 1801.6620 & $0.0000^{* * *}$ \\
\hline KP & 146.3669 & 1.0000 & 1796.3072 & $0.0000^{* * *}$ \\
\hline
\end{tabular}

Notes: All variables are logarithmized except for Recession; $*, * *, * * *$ indicate rejection of the null hypothesis at $10 \%, 5 \%$ and $1 \%$ significance level. 
Appendix 2: Panel regression results

Table 2A. Panel regression results of the effects of low growth and normal growth on the four material categories of DMC.

\begin{tabular}{|c|c|c|c|c|c|c|c|c|}
\hline \multirow[t]{2}{*}{ Variable } & \multicolumn{2}{|c|}{ DMC-Biomass } & \multicolumn{2}{|c|}{ DMC-Fossil Fuels } & \multicolumn{2}{|c|}{ DMC-Minerals } & \multicolumn{2}{|c|}{ DMC-Ores } \\
\hline & $\begin{array}{c}\text { Under low } \\
\text { growth }\end{array}$ & $\begin{array}{c}\text { Under } \\
\text { normal } \\
\text { growth }\end{array}$ & $\begin{array}{c}\text { Under low } \\
\text { growth }\end{array}$ & $\begin{array}{c}\text { Under } \\
\text { normal } \\
\text { growth }\end{array}$ & $\begin{array}{c}\text { Under low } \\
\text { growth }\end{array}$ & $\begin{array}{c}\text { Under } \\
\text { normal } \\
\text { growth }\end{array}$ & $\begin{array}{c}\text { Under low } \\
\text { growth }\end{array}$ & $\begin{array}{l}\text { Under } \\
\text { normal } \\
\text { growth }\end{array}$ \\
\hline Low growth & $\begin{array}{l}-0.0074 \\
(0.012)\end{array}$ & & $\begin{array}{l}-0.0250 \\
(0.008)\end{array}$ & & $\begin{array}{c}-0.0298 * * \\
(0.012)\end{array}$ & & $\begin{array}{l}0.0070 \\
(0.029)\end{array}$ & \\
\hline Normal growth & & $\begin{array}{l}-0.0209 \\
(0.010)\end{array}$ & & $\begin{array}{l}-0.0312 \\
(0.024)\end{array}$ & & $\begin{array}{l}-0.0035 \\
(0.010)\end{array}$ & & $\begin{array}{l}-0.0100 \\
(0.022)\end{array}$ \\
\hline
\end{tabular}

Note: control variables are omitted. 
Appendix 3: DMC and GDP growth rate of China and India, Italy and UK, from 1970 to 2010. China (Fig.3A) and India (Fig.3B) exhibit only few years with recession, but in both countries the development of DMC growth in general closely follows GDP and absolute dematerialization only occurred during or near years of recession. Italy (Fig. 3C) and UK (Fig.3D) are two more examples for high income countries which show declining DMC during years of recession or low growth, similar as Japan or Germany in Fig. 2 in the main text.
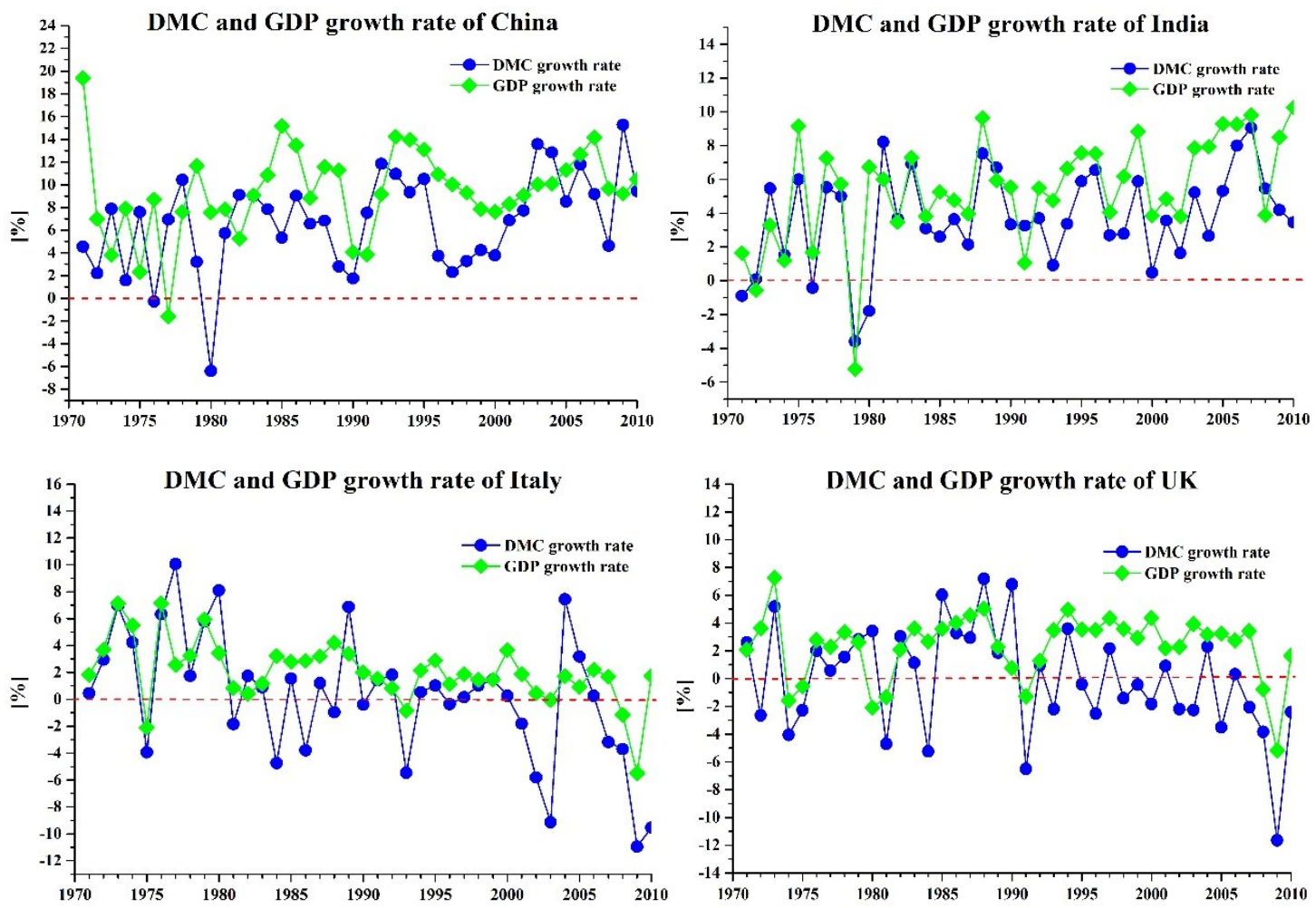

Fig.3. Gross domestic product (GDP) and domestic material consumption (DMC $=$ domestic extraction plus imports minus exports) growth rates in China, India, Italy and UK during 1970-2010. Please note the differences in scaling of the y-axis. Data sources: UNEP (2016b), World Bank (2016). 
Appendix 4: List of the 150 economies analyzed in this paper.

Afghanistan, Angola, Albania, Algeria, United Arab Emirates, Argentina, Australia, Austria, Burundi, Belgium, Benin, Burkina Faso, Bangladesh, Bulgaria, Bahrain, Belize, Bolivia, Brazil, Brunei Darussalam, Botswana, Central African Republic, Canada, Switzerland, Chile, China, Cote d'Ivoire, Cameroon, Congo, Rep., Colombia, Costa Rica, Cuba, Cyprus, Czech Republic, Germany, Denmark, Dominican Republic, Ecuador, Egypt, Arab Rep., Spain, Estonia, Ethiopia, Finland, Fiji, France, Gabon, United Kingdom, Georgia, Ghana, Guinea, Gambia, The, Guinea-Bissau, Equatorial Guinea, Greece, Guatemala, Guyana, Hong Kong SAR, China, Honduras, Croatia, Haiti, Hungary, Indonesia, India, Ireland, Iran, Islamic Rep., Iraq, Iceland, Israel, Italy, Jamaica, Jordan, Japan, Kenya, Kyrgyz Republic, Cambodia, Korea, Rep., Kuwait, Lao PDR, Lebanon, Libya, Sri Lanka, Lithuania, Luxembourg, Macao SAR, China, Morocco, Moldova, Madagascar, Mexico, Macedonia, FYR, Mali, Malta, Myanmar, Mongolia, Mozambique, Mauritania, Mauritius, Malaysia, Namibia, New Caledonia, Niger, Nigeria, Nicaragua, Netherlands, Norway, Nepal, New Zealand, Pakistan, Panama, Peru, Philippines, Papua New Guinea, Poland, Portugal, Paraguay, Qatar, Romania, Russian Federation, Rwanda, Saudi Arabia, Sudan, Senegal, Singapore, Sierra Leone, El Salvador, Suriname, Slovak Republic, Slovenia, Sweden, Syrian Arab Republic, Chad, Togo, Thailand, Tajikistan, Turkmenistan, Tonga, Trinidad and Tobago, Tunisia, Turkey, Tanzania, Uganda, Ukraine, Uruguay, United States, Venezuela, RB, Vietnam, Samoa, Yemen, Rep., South Africa, Congo, Dem. Rep., Zambia, Zimbabwe. 